- Luís Carlos Machado Junior

- Ana Sílvia Whitaker Dalmaso

- Heráclito Barbosa de Carvalho

\section{Evidence for benefits from treating cervical ectopy: literature review}

\author{
Centro de Saúde Escola Samuel Barnsley Pessoa, Faculdade de Medicina \\ da Universidade de São Paulo (FMUSP), São Paulo, Brazil
}

CONTEXT AND PURPOSE: Uterine cervical ectopy (cervical erosion) is today considered to be a physiological condition, but there still seems to be a strong tendency towards treating it. The purpose of this study was to review the medical literature for evidence regarding benefits from treating cervical ectopy.

METHODS: The following databases were reviewed: Medical Literature Analysis and Retrieval System Online (Medline), Excerpta Medica Database (Embase), Literatura Latino-Americana e do Caribe em Ciências da Saúde (Lilacs) and Cochrane Library databases. In addition, six medical textbooks were consulted.

RESULTS: The review showed that: 1) there is probably an association between ectopy and higher risk of Chlamydia trachomatis, human papillomavirus and human immunodeficiency virus infection; 4) there is probably an association between ectopy and cervical intraepithelial neoplasia; 5) there is an association between ectopy and mucous discharge and nocturia; and 6) there is no evidence of an association between ectopy and cervical cancer, or of protection against cervical cancer associated with ectopy treatment

CONCLUSIONS: 1) No data were found in the medical literature to support routine treatment for ectopy; 2) Treatment could be recommended for symptom relief, but more symptoms are attributed to ectopy than could be demonstrated in a controlled study; 3 ) Further studies to test the hypothesis of protection against cervical cancer associated with treatment are necessary.

KEY WORDS: Uterine cervical erosion. Uterine cervicitis. Cervical intraepithelial neoplasia. Uterine cervical dysplasia. Uterine cervical neoplasm.
INTRADUCTIDN

Uterine cervical ectopy is the occurrence of single-layered secreting columnar epithelium (which usually covers the cervical canal, i.e. the endocervix), beyond the external cervical orifice. Thus, the multilayered squamous epithelium typically found in the vagina and exocervix are replaced. ${ }^{1-3}$ This condition has many designations in medical terminology: ectropion, erythroplakia, macula rubra and erosion. ${ }^{1,2,4,5}$

Not all factors involved in the pathogenesis of cervical ectopy are known but there is an association with the action of estrogen. ${ }^{2,3,6}$ Ectopy is rare beyond the menopause and frequent at reproductive ages. It has higher prevalence during pregnancy ${ }^{2}$ and also among users of estrogen-based contraceptives. ${ }^{6-11}$ The rare examinations on newborns that have been reported show high prevalence, probably secondary to estrogens of pregnancy. ${ }^{12}$ There is also, starting in puberty, a negative association with age, even before the menopause. Some studies demonstrated a negative association with the number of years of sexual activity and number of partners. ${ }^{2,7}$

The natural history of ectopy is well established. After its development, a process of metaplasia occurs in the columnar epithelium, known as squamous metaplasia. ${ }^{1,3}$ All women go through this process, which may take months or years, and the exposed columnar epithelium is partially or fully converted into stratified squamous epithelium. The resulting area is known as the transformation zone. ${ }^{1,3}$

The prevalence reported for ectopy ranges from 17 to $50 \% \cdot{ }^{13,14}$ Given that its course is usually time-limited, the prevalence estimates in a population will detect only the women with ectopy at that time. In such populations, some women will already have had this condition and others will develop it. It is likely that most women, if not all, will have ectopy at some point during their lifetimes. ${ }^{4,6}$
Cervical ectopy and the associated squamous metaplasia are now considered to be physiological phenomena. ${ }^{1,15}$ Nonetheless, its management has historically consisted of interventions with the purpose of inducing or accelerating its regression. There seems to be a current trend towards less intervention, but it is still very common. Although the spontaneous process of metaplasia almost always leads to reduction or elimination of ectopy, this is a much slower process than the process resulting from treatment. The treatments currently available are electrocoagulation, cryocauterization, laser cauterization and drug treatment. ${ }^{16}$ Cauterization, in its several variants, is the treatment most often used. Patients are treated on an outpatient basis. The efficacy for cauterization is around $90 \%{ }^{16}$

There are several lines of argument that would support routine treatment for ectopy. The most common ones are:

a) Protection against cervical cancer. This is probably the argument most generally seen. There is a relationship between squamous metaplasia and induction of squamous cell carcinoma of the cervix. ${ }^{2,3,15}$ Cells undergoing metaplasia are more susceptible to carcinogens. Precancerous lesions often develop at the squamous-columnar junction, i.e. the area of transition between glandular and stratified epithelium, which is the location where metaplasia is most intense. ${ }^{15}$ Thus, theoretically, if this process could be made to occur over a shorter time span and if, by reducing ectopy, metaplasia would be less extensive, there would be a lower risk of cancer.

b) Some sexually transmitted microorganisms such as Chlamydia trachomatis and Neisseria gonorrhoeae preferentially infect glandular epithelium. Ectopy would, by exposing this epithelium, favor infection. ${ }^{15,17}$

c) Ectopy consists of secreting epithelium, and it is thus associated with increased 
mucus production, ${ }^{2,18}$ which may cause discomfort to women. Other symptoms are also sometimes attributed to ectopy, like pelvic pain and postcoital bleeding. ${ }^{14}$

We believe this is a major issue because of the high prevalence of ectopy. If it were decided to treat all women with ectopy, this would entail the utilization of substantial physical and human resources, even though the treatment is not complex. Hence the need to evaluate whether intervention produces any real benefit.

The objective of this study was to assess, through a comprehensive review of the literature, what the alleged indications for and benefits from treating ectopy are and, above all, whether these benefits are purely theoretical or are based on evidence from clinical and/or epidemiological studies.

METHODS

This study consisted of a literature review including searches in the Medical Literature Analysis and Retrieval System Online (Medline), Literatura Latino-Americana e do Caribe em Ciências da Saúde (Lilacs) and Cochrane Library databases up to July 2006; the Excerpta Medica Database (Embase) database from 1994 to 1999; and specialized books and references in books and selected articles. In addition, two professors of Gynecology at two different public universities in São Paulo, whose work has been focused on conditions of the lower genital tract and colposcopy, were consulted to ascertain whether they knew of any evidence in the literature regarding the benefits from treatment.

The review of the databases included the following approach: any study with ectopy as a main or secondary subject was searched. Once found, the titles and abstracts of the studies were evaluated. When there was any chance that a study somehow addressed the issue of benefits or indications for treatment, even indirectly, it was selected for analysis of its full text.

The protocol for this study was approved by the Ethics Committee of Hospital das Clínicas, Faculdade de Medicina da Universidade de São Paulo (HCFMUSP).

\section{RESULTS FROM THE} LITERATURE REVIEW

\section{BPECIALIZED BODKB}

Cartier and Cartier ${ }^{1}$ stated that ectopy is a physiological phenomenon and thus should not be treated. They also argued that, with treatment, the squamous-columnar junction is very often displaced up to the cervical canal, thereby making cervical cancer prevention more difficult. The book does not contain bibliographical references. De Palo ${ }^{4}$ recommended treatment because "stratified epithelium is more physiological in the exocervix". His opinion was not supported by bibliographical references. Pereyra and Guerra $^{16}$ recommended treatment, but they did not offer any arguments or references to support this.

Singer and Monaghan ${ }^{3}$, Berek et al. ${ }^{15}$, Piato ${ }^{19}$ and Pereyra et al. ${ }^{20}$ did not address the issue of treatment.

Table 1. Distribution of the articles selected, according to total number of references, keywords used and search database

\begin{tabular}{llll}
\hline Database searched & Keywords used & Total references & $\begin{array}{l}\text { Total selected } \\
\text { articles }\end{array}$ \\
\hline Medline & NLM 'Cervix diseases (MeSH) erosion' & 423 & 9 \\
& NLM 'Cervix erosion (MeSH)' & 381 & 2 \\
& NLM 'Cervix erosion' & 94 & 3 \\
& NLM '(Pubmed) ectopy' & 71 & 17 \\
& NLM 'Cervix diseases (MeSH) ectopy' & 19 & 1 \\
Bireme & 'Diseases of uterine cervix' & 1541 & 12 \\
& 'Cervix erosion' & 6 & 0 \\
Embase & 'Uterine cervix erosion' & 11 & 1 \\
& 'Uterine cervix disease' & 128 & 0 \\
Lilacs & Ectropion & 2 & 0 \\
& Ectopy & 4 & 0 \\
& Cauterization & 11 & 1 \\
& Diseases of uterine cervix & 198 & 0 \\
Cochrane Library & 'Ectopy and cervical' & 4 & 1 \\
(in controlled trials): & 'Ectropion and cervical' & 5 & 0 \\
& 'Erosion and cervical' & 19 & 0 \\
Total & & 2917 & $\mathbf{4 7}$ \\
\hline
\end{tabular}

Medline = Medical Literature Analysis and Retrieval System Online; Bireme = Biblioteca Regional de Medicina; Embase = Excerpta Medica Database; Lilacs = Literatura Latino-Americana e do Caribe em Ciências da Saúde.

Table 2. Authors who made suggestions regarding treatment for ectopy

\begin{tabular}{|c|c|c|c|c|}
\hline Author & Type of work & $\begin{array}{l}\text { Year of } \\
\text { publication }\end{array}$ & $\begin{array}{l}\text { Recommended } \\
\text { treatment }\end{array}$ & $\begin{array}{l}\text { Argument for } \\
\text { treatment }\end{array}$ \\
\hline Leppaluoto ${ }^{21}$ & Opinion article & 1974 & Yes & $\begin{array}{l}\text { Prevention of } \\
\text { cervical cancer }\end{array}$ \\
\hline Donahue $^{22}$ & Opinion article & 1976 & No & - \\
\hline Kauraniemi et al. ${ }^{59}$ & Cross-sectional study & 1978 & Yes & $\begin{array}{l}\text { Prevention of } \\
\text { cervical cancer }\end{array}$ \\
\hline De Punzio et al. ${ }^{61}$ & Cross-sectional study & 1984 & No & - \\
\hline Vonka et al..$^{60}$ & Cross-sectional study & 1984 & Yes & $\begin{array}{l}\text { Prevention of } \\
\text { cervical cancer }\end{array}$ \\
\hline La Vecchia et al. ${ }^{62}$ & Case-control study & 1985 & No & - \\
\hline Moreira et al. ${ }^{24}$ & Opinion article & 1990 & No & - \\
\hline Cartier and Cartier ${ }^{1}$ & Text in book & 1994 & No & - \\
\hline De Luca Brunori et al. ${ }^{25}$ & Laboratory study & 1994 & Yes & Better immunity \\
\hline Pereyra and Guerra ${ }^{16}$ & Text in book & 1994 & Yes & None \\
\hline $\mathrm{De} \mathrm{Palo}^{4}$ & Text in book & 1996 & Yes & Not clear \\
\hline Madej et al. ${ }^{23}$ & Opinion article & 1999 & No & - \\
\hline Rocha-Zavaleta et al. ${ }^{46}$ & Cross-sectional study & 2004 & Yes & $\begin{array}{l}\text { Prevention of } \\
\text { cervical cancer }\end{array}$ \\
\hline
\end{tabular}


A set of 48 studies was selected to be presented. One of these was a reference in another study. The two professors consulted said that they were unaware of any clinical evidence in the literature regarding benefits from treatment. No study regarded as relevant was left out of the analysis due to any language difficulty. Copies of eight studies not available in Brazil were imported.

Among the 48 studies selected, four expressed the authors' opinions, one was a laboratory study and 43 were clinical studies. The clinical studies included the following topics: associations between ectopy and cervical infection due to Chlamydia trachomatis and Neisseria gonorrhoeae, cytomegalovirus (CMV), human immunodeficiency virus (HIV), human papillomavirus (HPV) and cervical intraepithelial neoplasia (CIN); symptoms of ectopy; and cervical cancer and protection against this cancer by cauterization. Out of these 48 studies, four are not discussed here because they present major methodological flaws.

\section{AUTHIRE' 'RPINIINS}

Leppaluoto $^{21}$ was in favor of routine treatment, in order to prevent cervical cancer.

Donahue ${ }^{22}$ and Madej et al. ${ }^{23}$ believed that ectopy was a physiological phenomenon and should only be treated when symptomatic. Moreira et al. ${ }^{24}$, in addition to these arguments, maintained that treatment did not prevent cervical cancer.

\section{LABORATIRY BTUDY}

De Luca Brunori et al. ${ }^{25}$ studied asymptomatic women with ectopy and obtained biopsy samples from areas of ectopy and stratified epithelium. They found lower cellular immune activity in areas of ectopy. Based on this finding, they proposed that treatment should be undertaken routinely.

\section{CLINIGAL gTUDIEg}

\section{CHLAMYDIA AND GONOCOCCUS}

Nine cross-sectional studies ${ }^{7,86-32}$ using univariate analysis reported an association between cervical Chlamydia infection and ectopy. In another four cross-sectional studies ${ }^{10,11,33,34}$ and in one clinical trial, ${ }^{35}$ this association was maintained in multivariate analyses. A further two crosssectional studies ${ }^{36,37}$ showed that this association disappeared in the multivariate analysis and a cohort study ${ }^{38}$ found a strong tendency towards an association but did not reach significance.

Seven cross-sectional studies ${ }^{8,11,14,29,30,33,34}$ reported that there was no association between gonococcus and ectopy (Table 3).

\section{CYTOMEgalovirus}

Collier et al. ${ }^{39}$ studied the relationship between sexual activity and CMV infection. He found an association between cervical CMV infection and ectopy that disappeared in multivariate analysis that included age, schooling level and race.

\section{HIV}

Moss et al. ${ }^{40}$ conducted a cross-sectional study among 70 couples in which the men were HIV-positive. They found that the women with ectopy were at greater risk of being HIV-positive, and that this risk was maintained in multivariate analysis: odds ratio $(\mathrm{OR})=5 ; 95 \%$ confidence interval $(\mathrm{CI})=1.7-14.7 ; \mathrm{p}=0.007$.

In a cross-sectional study on 97 HIVpositive women, Clemetson et al. ${ }^{18}$ found a higher frequency of HIV isolation from the cervix and vagina in the women with ectopy. This association remained in the multivariate analysis: $\mathrm{OR}=5 ; 95 \% \mathrm{CI}=1.5-16.9$; $\mathrm{p}=0.006$.

Plourde et al. ${ }^{41}$ conducted a cohort study on 134 HIV-negative women with genital ulcers. The group was followed up monthly for six months and infection with the HIV virus during this period was correlated with the women's characteristics. They found an association between ectopy and risk of HIV infection: relative risk $(\mathrm{RR})=3.9 ; 95 \% \mathrm{CI}=1.2-12.7$; and also an association between ectopy and shorter time for seroconversion.

Mati et al. ${ }^{42}$ conducted a cross-sectional study comprising 4,404 women in family planning clinics, to assess the association between the risk of HIV infection and contraceptive methods. Ectopy was also assessed, given the association with oral contraceptive use. Out of all of these women, $4.9 \%$ were HIV-positive. No association was found between HIV infection and ectopy.

Moscicki et al. ${ }^{43}$ conducted a cross-sectional study among $189 \mathrm{HIV}$-positive adolescents and $92 \mathrm{HIV}$-negative adolescents. Factors

Table 3. List of studies selected according to the association between Chlamydia infection and ectopy

\begin{tabular}{|c|c|c|c|c|c|c|c|c|}
\hline Author & Year & Location & Study design & Type of analysis & Association & MA & $95 \% \mathrm{Cl}$ & p-value \\
\hline Ripa et al. ${ }^{26}$ & 1978 & Sweden & Cross-sectional & Univariate & Yes & & & \\
\hline Hobson et al. ${ }^{7}$ & 1980 & England & Cross-sectional & Univariate & Yes $^{*}$ & $x^{2}=9.98$ & & 0.01 \\
\hline Tait et al. ${ }^{27}$ & 1980 & England & Cross-sectional & Univariate & Yes & $x^{2}=12.5$ & & 0.0004 \\
\hline Arya et al. ${ }^{8}$ & 1981 & England & Cross-sectional & Univariate & Yes & $x^{2}=24.34$ & & 0.001 \\
\hline Mallinson et al. ${ }^{32}$ & 1982 & England & Cross-sectional & Univariate & Yes $^{*}$ & $x^{2}=3.96$ & & 0.05 \\
\hline Chacko and Lovchik ${ }^{29}$ & 1984 & US & Cross-sectional & Univariate & Yes & & & \\
\hline Wood et al. ${ }^{28}$ & 1984 & England & Cross-sectional & Univariate & Yes & $x^{2}=9.24$ & & 0.001 \\
\hline Harrison et al. ${ }^{10}$ & 1985 & US & Cross-sectional & Multivariate & Yes $^{\dagger}$ & & & \\
\hline Handsfield et al. ${ }^{36}$ & 1986 & US & Cross-sectional & Multivariate & No & & & \\
\hline Blythe et al..$^{33}$ & 1988 & US & Cross-sectional & Multivariate & Yes & & & \\
\hline Louv et al. ${ }^{30}$ & 1989 & US & Cross-sectional & Univariate & Yes & $R R=1.49$ & $1.12-1.97$ & 0.005 \\
\hline Paavonen et al. ${ }^{35}$ & 1989 & Sweden & Clinical trial & Multivariate & Yes & & & \\
\hline Rahm et al. ${ }^{31}$ & 1990 & Sweden & Cross-sectional & Univariate & Yes & $x^{2}=9.6$ & & 0.01 \\
\hline Rahm et al. ${ }^{38}$ & 1991 & Sweden & Cohort & Univariate & No & $R R=1.78$ & $0.95-3.33$ & \\
\hline Stergachis et al. ${ }^{34}$ & 1993 & US & Cross-sectional & Multivariate & Yes & $O R=3.7$ & $2-6.9$ & \\
\hline Critchlow et al. ${ }^{11}$ & 1995 & US & Cross-sectional & Multivariate & Yes & $O R=2.4$ & $1.5-3.9$ & \\
\hline Jacobson et al. ${ }^{37}$ & 2000 & US & Cross-sectional & Multivariate & No & $O R=1.94$ & $0.40-2.39$ & \\
\hline
\end{tabular}

"Association between infection intensity and ectopy; ${ }^{\dagger}$ Multivariate analysis did not include ectopy individually but, rather, a score including ectopy. 
associated with their HIV status, including ectopy, were studied. Ectopy was measured through computerized analysis. The univariate analysis showed a negative association between ectopy and HIV infection, which remained in the multivariate analysis: $\mathrm{OR}=0.55 ; 95 \%$ $\mathrm{CI}=0.31-0.98 ; \mathrm{p}=0.04$ (Table 4).

\section{HPV AND CIN}

Toon et al. ${ }^{44}$ conducted a cross-sectional study among 210 women to identify factors associated with inflammatory cytological conditions. He found a much higher frequency of HPV in biopsies from women with ectopy (all the participants underwent biopsy; statistical data not available).

Duttagupta et al. ${ }^{45}$ conducted a crosssectional study on 850 women to assess the validity of detection of HPV subtypes 16 and 18 (which were considered to be oncogenic) as an approach for cervical cancer screening. An association between ectopy and HPV $(\mathrm{OR}=2.09 ; \mathrm{p}=0.005)$ was found.

In a cross-sectional study, Rocha-Zavaleta et al. ${ }^{46}$ found a higher general HPV rate and also a higher rate of HPV 16 in women with ectopy. However, the association was not significant, either for HPV in general $(\mathrm{OR}=2.06 ; 95 \% \mathrm{CI}=0.99-4.33)$ or for $\mathrm{HPV}$ $16(\mathrm{OR}=6.47 ; 95 \% \mathrm{CI}=0.88-133)$. They proposed routine treatment for ectopy, in areas with high HPV prevalence, to prevent cervical cancer.

Castle et al. ${ }^{47}$ studied the relationship between ectopy and two different groups of HPV: the alpha 9 group (mostly oncogenic) and the alpha 3/alpha 15 group (mostly non-oncogenic). A significantly higher rate of ectopy was found in women with the non-oncogenic group than in the other group (control group). They also found an association between infection in the oncogenic group and younger age. They suggested that the greater oncogenicity in this group could be due to higher affinity to metaplastic epithelium in young women.

Moscicki et al. ${ }^{48}$ conducted a case-control study on 18 adolescents with CIN and 204 controls. Among other variables, ectopy was assessed using computer-processed images. They found an association between these variables $(\mathrm{RR}=4.27 ; 95 \% \mathrm{CI}=1.45-12.45)$.

Sarkar and Steele ${ }^{49}$ conducted a study on 100 women who had been referred to a clinic for ectopy treatment. All of these women had normal cervical cytology. All underwent colposcopy and, if needed, cervical biopsy prior to treatment. CIN was found in 19 patients, and five of them had high-grade lesions. The authors considered that this CIN prevalence (both the high and low-grade, types) was greater than the expected rate for this population.

Moscicki et al..$^{50}$ conducted a case-control study comprising 75 adolescents with CIN and 75 controls. These were followed up for an average of 32 months. The authors found an association between CIN and the intensity of metaplasia (which is related to ectopy), immediately before CIN was diagnosed: $\mathrm{OR}=3 ; 95 \% \mathrm{CI}=1.3-6.82$.

\section{SYMPTAMs}

Goldacre et al. ${ }^{14}$ conducted a crosssectional study correlating epidemiological features and symptoms with ectopy. They studied 1,498 women who had sought out a family planning center. Ectopy was evaluated through clinical examination. The women were asked about symptoms that are attributed to ectopy, such as vaginal discharge, vulvar pruritus, low back pain, postcoital bleeding, painful intercourse, dysuria, nocturia, and pollakiuria. Tests for pathogenic microorganisms of the cervix and vagina were also conducted: Trichomonas vaginalis, fungi, and gonococcus and the bacterial flora of the vagina. The person who performed the examination (for detecting ectopy) was unaware of the subjects' symptoms and the person who evaluated the symptoms was unaware of the existence of ectopy. Ectopy was found in 550 women (36.7\%). There was no association between ectopy and fungal, Trichomonas vaginalis or gonococcal infection. No differences were seen in the bacte- rial flora of the vagina. In the multivariate analysis, which included mucus discharge, nocturia, parity, contraceptive method and evaluating physician, only the associations with mucus discharge and nocturia remained $(\mathrm{p}<0.05)$.

\section{CERVICAL CANCER (TABLE 5)}

Simm and Doltaniak ${ }^{51}$ suggested that there was an association between ectopy and cervical cancer. However, their conclusion was based on a study with serious methodological flaws and therefore it will not be discussed further here.

The Jiangxi Cooperative Group of Cervical Cancer ${ }^{52}$ conducted a case-control study in China, in 1980. They studied 306 women with cervical cancer and 306 controls. Thirty-six variables were investigated through direct interview. They found an association with ectopy.

Zhang and $\mathrm{Xu}^{53}$ conducted a case-control study comprising 125 cases of cervical cancer and 125 controls in China. Associations between 39 variables and cancer occurrence were assessed. In the multivariate analysis, the association with ectopy was maintained, among others.

Juneja et al. ${ }^{54}$ conducted a cross-sectional study to identify variables that were associated with cervical cancer. They studied 67,000 women who underwent a cytology test. At the time of data collection, all women underwent an examination. The cervix was classified as normal or presenting ectopic bleeding upon touch, "suspicious appearance" or "unhealthy" appearance. A total of 250 women (0.4\%) had cytological findings suggestive of invasive cancer, which, for the purposes of that study, was considered to be the definition of cancer. A significant association between cancer and all variables was seen, including ectopic bleeding upon touch.

Murthy et al. ${ }^{55}$ organized a cohort consisting of 1,107 women with cytological findings suggestive of CIN. They were followed up at three to six-month intervals with colposcopy, and biopsy if necessary, along

Table 4. List of studies selected according to association between ectopy and HIV infection

\begin{tabular}{lcccccccc}
\hline Author & Year & Location & Study design & Type of analysis & Association & Measurement of association & $95 \% \mathrm{Cl}$ & $\mathrm{p}$-value \\
\hline Moss et al.40 & 1991 & Kenya & Cross-sectional & Multivariate & Yes & OR $=5$ & $1.7-14.7$ & 0.007 \\
Clemetson et al. ${ }^{18}$ & 1993 & Kenya & Cross-sectional & Multivariate & Yes ${ }^{*}$ & OR $=5$ & $1.5-16.9$ & 0.06 \\
Plourde et al.41 & 1994 & Kenya & Cohort & Univariate & Yes & RR $=4.9$ & $1.5-15.9$ & 0.02 \\
Mati et al.42 & 1995 & Kenya & Cross-sectional & Univariate & No & OR $=1.3$ & $0.7-2.1$ & - \\
Moscicki et al. ${ }^{43}$ & 2001 & US & Cross-sectional & Multivariate & Yes (negative) & OR $=0.55$ & $0.31-0.98$ & 0.04 \\
\hline
\end{tabular}

"Association between ectopy and viral isolation from vaginal and cervical discharges among HIV-positive women.

$\mathrm{Cl}=$ confidence interval; $O R=$ odds ratio; $R R=$ relative risk; $U S=$ United States. 
with cytological tests. Associations between progress to in situ carcinoma and the following variables were studied: age (35 years or over), use or nonuse of contraception, parity, fetal losses, Herpes simplex I and II status and ectopy. Over the course of 78 months of follow-up, 75 women progressed to in situ carcinoma. In the multivariate analysis, only the association with age at marriage was maintained $(p=0.02)$. No association with ectopy was found.

Kanka et al. ${ }^{56}$, Bouda and Dohnal ${ }^{57}$ and Peyton et al. ${ }^{58}$ conducted studies to investigate cancer prevention using cauterization. However, these studies presented methodological flaws that made them inconsistent, and thus they will not be discussed further here.

Kauraniemi et al..$^{59}$ conducted a crosssectional population-based study among 429,832 women who underwent cervical cancer screening with cytological tests. They correlated histories of cauterization due to any indication at any time with the detection of malignant or premalignant histological lesions. They found a negative association between cauterization and neoplastic and preneoplastic cervical lesions. The relative risks were: low-grade dysplasia, 0.40; high-grade dysplasia, 0.24; in situ carcinoma, 0.23 ; and invasive carcinoma, 0.15 . After stratification by age, the association remained. After stratification by marital status, the association disappeared for single women. They concluded that cauterization protected against cervical cancer and noted that this protection might be greater than the protection resulting from mass screening programs.

\section{CANCER PREVENTION USING CAUTERIZATION}

Vonka et al. ${ }^{60}$ conducted a cross-section study among 10,683 women to identify risk factors for CIN. They found a protective effect for history of cauterization: $24.6 \%$ of the controls had cauterization versus $13.4 \%$ of the women with cervical intraepithelial neoplasia grade I (CIN I), $6.9 \%$ of those with CIN II, $8.7 \%$ of those with CIN III and $9.5 \%$ of those with in situ carcinoma $(\mathrm{p}<0.05)$. They concluded that ectopy should be cauterized to prevent cervical cancer.

De Punzio et al. ${ }^{61}$ conducted a cross-sectional study among 2,001 women in a private clinic for cervical cancer prevention. They compared the prevalence of preneoplastic and neoplastic lesions with histories of cauterization at any time and due to any indication. They found no association.

La Vecchia et al. ${ }^{62}$ conducted a casecontrol study with the specific objective of assessing whether electrocoagulation of ectopy protected against cervical cancer. Two case-control studies were conducted simultaneously. In the first study, the cases were 191 women with invasive cervical cancer and there were 191 controls. The second study had the same format as the first one, except that the cases were women with CIN.

In their first study, on invasive carcinoma, the univariate analysis showed an apparent protective effect among cauterized women: $\mathrm{RR}=0.42 ; 95 \% \mathrm{CI}=0.22-0.82$. After adjusting for the number of cervical cytological tests (none, one, or two or more), it was found that the RR increased to 0.83 and was no longer significant $(95 \%$ $\mathrm{CI}=0.40-1.72)$. In the multivariate analysis, which included age, education, parity, number of sexual partners, age at first sexual

Table 5. Studies that evaluated the association between ectopy and cervical cancer

\begin{tabular}{lccc}
\hline Author & Type of Study & Year of publication & Association \\
\hline Jiangxi Group ${ }^{52}$ & Case-control & 1986 & Yes \\
Murthy et al. ${ }^{55}$ & Cohort & 1990 & No \\
Zhang and Xu ${ }^{53}$ & Case-control & 1990 & Yes \\
Juneja et al. ${ }^{54}$ & Case-control & 1993 & Yes \\
\hline
\end{tabular}

Table 6. List of studies selected according to the association between cervical cancer and cauterization of ectopy

\begin{tabular}{lccccc}
\hline Author & Year & Location & Type of analysis & Protection $\begin{array}{c}\text { Measurement } \\
\text { of protection* }\end{array}$ \\
\hline Kauraniemi et al. ${ }^{59}$ & 1978 & Finland & Univariate & Yes & RR $=0.15$ \\
Vonka et al. ${ }^{60}$ & 1984 & Czechoslovakia & Univariate & Yes & \\
De Punzio et al. ${ }^{61}$ & 1984 & Italy & Univariate & No & \\
La Vecchia et al. ${ }^{62}$ & 1985 & Italy & Multivariate & No & RR $=0.94$ \\
\hline
\end{tabular}

${ }^{*}$ Confidence intervals and $p$-values not made available by the authors. $R R=$ relative risk. intercourse and use of oral contraceptives, it reached as high as 0.94 . Within the same stratum of cytological tests, adjusting for cauterization did not change the relative risk. In the second study, among women with CIN, the same sequence of results was found.

These authors (La Vecchia et al. ${ }^{62}$ ) cited the aforementioned studies of Peyton et al..$^{58}$, Kauraniemi et al. ${ }^{59}$ and Vonka et al. ${ }^{60}$ as major references on this issue. They stated that, differently from those other studies, their study showed evidence against the protective effect of cauterization for cervical cancer (Table 6).

\section{DIBCUBSIN F THE BTUDIEG}

As mentioned earlier, few studies have been conducted to evaluate the benefits from routine treatment for ectopy. In the Cochrane Library's review, for example, only the efficacy of treatments for ectopy regression was discussed.

The small number of studies reviewing the validity of routine treatment indicates that the medical scientific community has not been greatly interested in answering this question, even though treatment for ectopy is a very common intervention. The large number of articles dealing exclusively with treatment approaches corroborates this statement.

The lack of correlation between scientific evidence for benefits and the widely practiced treatments makes it clear that, in the medical field, the clinical management methods are not only supported by recent scientific knowledge. Some authors have pointed out that Medicine has the characteristics of a practice that is supported by scientific knowledge but connected to other areas of social life ${ }^{63,64}$ and based on the physician's performance. The physician is not only a knowledge holder but also an individual who possesses values, beliefs and motivations. ${ }^{65}$

If, on the one hand, up-to-date scientific knowledge is paramount, as seen in the present study, physicians tend to recognize knowledge acquired both at medical school, during interactions with teachers, and in their clinical experience, in autonomous practice. Physicians make therapeutic decisions based on a set of sources, with varying levels of patient involvement.

Thus, there were several articles that, although they did not address the main concern of the present study, suggested associations between ectopy and certain diseases or symptoms. These will be discussed now. 


\section{GaNacaccus}

None of the seven studies investigating associations between ectopy and gonococcal infection was able to confirm such an association. ${ }^{8,11,14,29,30,33,36}$ It can be concluded these conditions are not associated.

\section{CHLAMYDIA}

An association between Chlamydia infection and ectopy can be assumed to be very likely. Out of the 17 studies investigating this, 14 found an association (five also in multivariate analysis) and only three did not show it. Among these three, the study by Rahm et al. ${ }^{38}$ showed a higher frequency of infection among women with ectopy, but had a small sample and was not statistically significant $(\mathrm{OR}=1.78 ; 95 \% \mathrm{CI}=0.95-3.33)$.

It can also be assumed that a cause-effect relationship is likely, such that ectopy favors infection, given the affinity of Chlamydia for glandular epithelium. ${ }^{17}$ Supposing these hypotheses to be true, it can be assumed that treatment for ectopy could reduce the risk of Chlamydia infection.

There would be no sense, however, in treating all women with ectopy with this purpose. Based on the Chlamydia studies reviewed here, the infection prevalence ranges from $3.7 \%$ to $35 \%$; the former rate is probably closer to that of the general population, since it was estimated in a primary care service. ${ }^{11}$ In Brazilian studies, the infection rates have ranged from $4 \%$ to $11.2 \% .^{66-68}$ It should be underlined that most infected women are asymptomatic, and represent a problem only in that they may be possible carriers of infection. ${ }^{17}$ Since the prevalence of ectopy is high, its treatment would be an intervention of little benefit, given the large population to be treated. Moreover, there are strategies for managing Chlamydia infection in the general population that are more effective. Nonetheless, there could be specific situations in which such interventions would be effective, for instance, in cases of women with high exposure to sexually transmitted diseases and some difficulty in getting their partners to use condoms regularly.

\section{HIV}

A similar discussion holds for HIV infection. It can be assumed that women with ectopy are likely to be susceptible to HIV infection. However, the studies presented here showed contradictory results. One likely explanation for these inconsistencies is that, when exposed to HIV, women with ectopy are at higher risk of infection, probably due to lower immune competence of their glandular epithelium. ${ }^{24}$ Ectopy is, however, inversely associated with age and sexual exposure. ${ }^{11}$ Women with ectopy would thus comprise a group at lower risk of HIV exposure, since they are on average younger and have lower sexual exposure. In the study by Moss et al. ${ }^{40}$, all the women were exposed to an HIV-positive partner and, consequently, women with ectopy were more infected. In the studies by Mati et al. ${ }^{42}$ and Moscicki et al. ${ }^{43}$, the women with ectopy were drawn from the general population and thus were less likely to be exposed to HIV, hence the lack of association or negative association found. In the study by Plourde et al. ${ }^{41}$, since all the women had genital ulcers, they probably comprised a group with higher exposure to sexually transmitted diseases and therefore to HIV.

On the other hand, assuming that this population has higher susceptibility, it would be pointless to treat all women with ectopy to reduce this risk, even with regard to fatal conditions. It would be an extensive therapeutic intervention of low efficacy. Even if it were believed that treatment provided some protection, it would never provide full protection. In the same way as with Chlamydia infection, particular situations could be envisaged in which treatment would be justifiable, for example, cases of HIV-negative women with HIV-positive partners.

The alleged benefits in these specific situations are, however, only theoretically inferred on the basis of the present review. They have not been proven across the population. For example, among the studies reviewed that dealt with the issues of HIV and Chlamydia, none of them even mentioned treatment for ectopy. Their focus was basically on identifying risk markers for those infections.

\section{SYMPTDMATIC ECTQPY}

It is accepted that ectopy should be treated when there are symptoms attributable to this condition that cause discomfort. However, Goldacre et al. ${ }^{14}$ showed that more symptoms are attributed to ectopy than are actually caused by it.

\section{HPV AND CIN}

All four studies dealing with HPV infection and ectopy ${ }^{44,45,59,60}$ showed an association between these conditions. Three of them showed associations with oncogenic subtypes. Three studies dealing with associations between ectopy and CIN were reviewed. ${ }^{48,50}$ The study by Sarkar and Steele ${ }^{49}$ suggested that there was an association between CIN and ectopy, and both studies by Moscicki et al. ${ }^{48,50}$ showed an association between these conditions. If it is assumed that there is an association between ectopy and both HPV and CIN, and that ectopy favors the occurrence of these two conditions (a more likely scenario) rather than these conditions favoring the occurrence of ectopy, ectopy should be taken to be a risk factor for cervical cancer.

However, the seven studies discussed above do not provide evidence for such an association. CIN and HPV do not have a direct relationship with cervical cancer, even when oncogenic virus subtypes are involved. Based on these studies, it can be said that the ultimate argument in support of carrying out interventions to treat ectopy would be if it prevented cervical cancer. This issue will be further discussed below.

\section{CERVical cancer}

The existence of an association between ectopy and cervical cancer would, in theory, be the most important argument in favor of routine treatment. Cervical cancer is a severe disease that is usually fatal when not treated in a timely manner. ${ }^{2}$ An intervention leading to a reduction of, for example, $15 \%$ of the incidence rate expected for a specific population (taking the protection factor estimated in the study by Kauraniemi et al. ${ }^{59}$ ) would have a great impact on the mortality and morbidity caused by this disease. If this protection actually exists, it would justify searching for and treating all detected cases of ectopy.

Both of the case-control studies that investigated this issue (Jiangxi Co-operative Group of Cervical Cancer ${ }^{52}$ and Zhang and $\mathrm{Xu}^{53}$ ) reported that such an association existed. In both studies, however, the alleged risk factors were assessed through a questionnaire applied to women and it is possible that there may have been some classification bias. When cancer patients are clinically examined before their cancer has been diagnosed, they could be considered to present ectopy (erosion), which can be clinically mistaken for incipient cancer.

In the study by Juneja et al. ${ }^{54}$, bias is even more likely. The cancer diagnosis was made based on cytological data collected during the same evaluation as when ectopy was detected. In this case, it is very likely that well-established cancer was misdiagnosed as "ectopic bleeding upon touch".

In contrast, in the cohort studied by Murthy et al. ${ }^{55}$, all the participants underwent colposcopy, which is the best approach for diagnosing ectopy. These authors did not find any association between ectopy and progression to in situ carcinoma. 


\section{CANCER PREVENTION USING}

\section{GAUTERIZATION}

The studies by Kauraniemi et al. ${ }^{59}$ and Vonka et al. ${ }^{60}$ suggested that cauterization would have a protective effect, but not all possible confounders were properly controlled for.

The most convincing study is certainly the one by La Vecchia et al. ${ }^{62}$ Based on arguments developed in previous studies, they questioned them using proper methodology. Although three earlier studies had demonstrated apparent protection, the study by La Vecchia et al. ${ }^{62}$ was specifically designed to explore this issue and showed that treatment for ectopy, is a confounder for cervical cytological findings.
The protection factor, which was of magnitude similar to what had been found by other authors, disappeared after controlling for the number of cytological tests. After stratifying according to the number of cytological tests, the history of cauterization did not change the risk of cervical cancer.

Therefore, it can be said that the current evidence does not support the hypothesis that treatment for ectopy provides protection against cervical cancer. It is remarkable that the study by La Vecchia et al. ${ }^{62}$ was published as long ago as 1985 . In the present review, no studies of more recent date that retested this hypothesis were found.

\section{CᄆNCLUSIRN}

The present study allows the following conclusions:

- No data in the medical literature was found supporting routine treatment for ectopy.

- Treatment can be used to relieve occasional symptoms associated with ectopy. However, more symptoms are attributed to this condition than can be confirmed in a controlled study.

- Further studies designed to test the hypothesis that protection against cervical cancer is provided by treatment for ectopy are needed.
1. Cartier R, Cartier I. Colposcopia prática. $3^{\text {rd }}$ ed. São Paulo: Roca; 1994.

2. Halbe HW. Tratamento de ginecologia. $2^{\text {nd }}$ ed. São Paulo: Roca; 1994

3. Singer A, Monaghan JM. Colposcopia, patologia e tratamento do trato genital inferior. Porto Alegre: ARTMED; 1995.

4. De Palo G. Colposcopia e patologia do trato genital inferior. 2 ed. Rio de Janeiro: Medsi; 1996.

5. Rieper JP, Fonseca NM. Patologia cervical. São Paulo: Manole; 1978

6. Schivartche PL, Fonseca AM. Impacto homonal na cérvice. [Hormonal driver against in the cervix]. Rev Ginecol Obstet. 1997;8(2):100-2

7. Hobson D, Karayiannis P, Byng RE, Rees E, Tait IA, Davies JA. Quantitative aspects of chlamydial infection of the cervix. Br J Vener Dis. 1980;56(3):156-62.

8. Arya OP, Mallinson H, Goddard AD. Epidemiological and clinical correlates of chlamydial infection of the cervix. $\mathrm{Br} J$ Vener Dis. 1981;57(2):118-24.

9. Ruiz-Moreno JA. Meaning of the word erosion. Gynecol Oncol. 1981;12(2 Pt 1):268.

10. Harrison HR, Costin M, Meder JB, et al. Cervical Chlamydia trachomatis infection in university women: relationship to history, contraception, ectopy, and cervicitis. Am J Obstet Gynecol. 1985;153(3):244-51.

11. Critchlow CW, Wölner-Hanssen P, Eschenbach DA, et al. Determinants of cervical ectopia and of cervicitis: age, oral contraception, specific cervical infection, smoking, and douching. Am J Obstet Gynecol. 1995;173(2):534-43.

12. Terruhn V. Die Ektopie in der Neugeborenenperiode. Eine vaginoskopische Studie. [Vaginoscopic investigation of the cervical ectopy in the neonate (author's transl)]. Geburtshilfe Frauenheilkd. 1979;39(7):568-73.

13. Carrera JM, Dexeus S, Coupez F. Cuello inflamatorio. In Carrera JM, Dexeus Jr. S, Coupez F, editors. Tratado y atlas de colposcopia. Barcelona: Salvat; 1974. p. 28-54.

14. Goldacre MJ, Loudon N, Watt B, et al. Epidemiology and clinical significance of cervical erosion in women attending a family planning clinic. Br Med J. 1978;1(6115):748-50.

15. Berek JS, Adashi EY, Hillard PA. Novak: tratado de ginecologia. Rio de Janeiro: Guanabara Koogan; 1998

16. Pereyra E, Guerra D. Cervicite. In: Halbe HW, editor. Tratamento de ginecologia. $2^{\text {nd }}$ ed. São Paulo: Roca; 1994. p. 882-92.

17. Monif GRG. Infectious diseases in obstetrics and gynecology. $2^{\text {nd }}$ ed. Philadelphia: Harper \& Row; 1982

18. Clemetson DB, Moss GB, Willerford DM, et al. Detection of HIV DNA in cervical and vaginal secretions. Prevalence and correlates among women in Nairobi, Kenya. JAMA. 1993;269(22):2860-4

19. Piato S. Tratado de ginecologia. $2^{2}$ ediçăo. São Paulo: Artes Médica; 2002
20. Pereyra E, Dias MN, Parellada L. Cervicite In: Halbe HW, editor. Tratado de Ginecologia. $3^{a}$ ed. São Paulo: Roca; 2000. p. 1069-78.

21. Leppaluoto P. Letter: Contraceptive choice and cervical cytology. Am J Obstet Gynecol. 1974;118(4):581.

22. Donahue VC. The cervical "erosion": myth and reality. J Am Coll Health Assoc. 1976;24(3):167-8.

23. Madej J, Basta A, Madej JG, Strama M. Wspólczesny model postepowania w przypadkach erytroplakii. [Contemporary model for treatment of erythroplakia]. Przegl Lek. 1999;56(1):5-13.

24. Moreira MA, Mussiello R, Rivoire WA. Cauterização do colo uterino: quando e como usar? [Uterus cautery: whem and how to use it?]. Femina. 1990;18(4):289-91.

25. De Luca Brunori I, Facchini V, Filippeschi M, et al. Cell-mediated immunity in the course of cervical ectropion. Clin Exp Obstet Gynecol. 1994;21(2):105-7.

26. Ripa KT, Svensson L, Mardh PA, Weström L. Chlamydia trachomatis cervicitis in gynecologic outpatients. Obstet Gynecol. 1978;52(6):698-702

27. Tait IA, Rees E, Hobson D, Byng RE, Tweedie MC. Chlamydial infection of the cervix in contacts of men with nongonococcal urethritis. Br J Vener Dis. 1980;56(1):37-45.

28. Wood PL, Hobson D, Rees E. Genital infections with Chlamydia trachomatis in women attending an antenatal clinic. $\mathrm{Br}$ J Obstet Gynaecol. 1984;91(12):1171-6.

29. Chacko MR, Lovchik JC. Chlamydia trachomatis infection in sexually active adolescents: prevalence and risk factors. Pediatrics. 1984;73(6):836-40.

30. Louv WC, Austin H, Perlman J, Alexander WJ. Oral contraceptive use and the risk of chlamydial and gonococcal infections. Am J Obstet Gynecol. 1989;160(2):396-402.

31. Rahm VA, Odlind V, Gnarpe H. Chlamydia trachomatis among sexually active teenage girls: influence of sampling location and clinical signs on the detection rate. Genitourin Med. 1990;66(2):66-9.

32. Mallinson H, Arya OP, Goddard AD. Quantitative study of Chlamydia trachomatis in genital infection. Br J Vener Dis. 1982;58(1):36-9

33. Blythe MJ, Katz BP, Orr DP, Caine VA, Jones RB. Historical and clinical factors associated with Chlamydia trachomatis genitourinary infection in female adolescents. J Pediatr. 1988;112(6):1000-4.

34. Stergachis A, Scholes D, Heidrich FE, Sherer DM, Holmes KK, Stamm WE. Selective screening for Chlamydia trachomatis infection in a primary care population of women. Am J Epidemiol. 1993;138(3):143-53.

35. Paavonen J, Roberts PL, Stevens CE, et al. Randomized treatment of mucopurulent cervicitis with doxycycline or amoxicillin. Am J Obstet Gynecol. 1989;161(1):128-35.

36. Handsfield HH, Jasman LL, Roberts PL, Hanson VW, Kothenbeutel RL, Stamm WE. Criteria for selective screening for Chlamydia trachomatis infection in women attending family planning clinics. JAMA. 1986;255(13):1730-4.
37. Jacobson DL, Peralta L, Farmer M, Graham NM, Gaydos C, Zenilman J. Relationship of hormonal contraception and cervical ectopy as measured by computerized planimetry to chlamydial infection in adolescents. Sex Transm Dis. 2000;27(6):313-9.

38. Rahm VA, Odlind V, Pettersson R. Chlamydia trachomatis in sexually active teenage girls. Factors related to genital chlamydial infection: a prospective study. Genitourin Med. 1991;67(4):317-21.

39. Collier AC, Handsfield HH, Ashley R, et al. Cervical but not urinary excretion of cytomegalovirus is related to sexual activity and contraceptive practices in sexually active women. J Infect Dis. 1995;171(1):33-8.

40. Moss GB, Clemetson D, D'Costa L, et al. Association of cervical ectopy with heterosexual transmission of human immunodeficiency virus: results of a study of couples in Nairobi, Kenya. J Infect Dis. 1991;164(3):588-91.

41. Plourde PJ, Pepin J, Agoki E, et al. Human immunodeficiency virus type 1 seroconversion in women with genital ulcers. J Infect Dis. 1994;170(2):313-7.

42. Mati JK, Hunter DJ, Maggwa BN, Tukei PM. Contraceptive use and the risk of HIV infection in Nairobi, Kenya. Int J Gynaecol Obstet. 1995;48(1):61-7.

43. Moscicki AB, Ma Y, Holland C, Vermund SH. Cervical ectopy in adolescent girls with and without human immunodeficiency virus infection. J Infect Dis. 2001;183(6): 865-70.

44. Toon PG, Arrand JR, Wilson LP, Sharp DS. Human papillomavirus infection of the uterine cervix of women without cytological signs of neoplasia. Br Med J (Clin Res Ed). 1986;293(6557):1261-4.

45. Duttagupta C, Sengupta S, Roy M, et al. Oncogenic human papillomavirus (HPV) infection and uterine cervical cancer: a screening strategy in the perspective of rural India. Eur J Cancer Prev. 2002;11(5):447-56

46. Rocha-Zavaleta L, Yescas G, Cruz RM, Cruz-Talonia F. Human papillomavirus infection and cervical ectopy. Int J Gynaecol Obstet. 2004;85(3):259-66.

47. Castle PE, Jeronimo J, Schiffman M, et al. Age-related changes of the cervix influence human papillomavirus type distribution. Cancer Res. 2006;66(2):1218-24.

48. Moscicki AB, Winkler B, Irwin CE, Schachter J. Differences in biologic maturation, sexual behavior, and sexually transmitted disease between adolescents with and without cervical intraepithelial neoplasia. J Pediatr. 1989;115(3):487-93.

49. Sarkar PK, Steele PRM. Routine colposcopy prior to treatment of cervical ectopy: is it worthwhile? Journal of Obstetrics and Gynaecology. 1996;16(2):96-7. Available from: http://direct. bl.uk/bld/PlaceOrder.do?UIN=025645777\&ETOC=RN\&fr om=searchengine. Accessed in 2008 (Feb 13).

50. Moscicki AB, Burt VG, Kanowitz S, Darragh T, Shiboski S. The significance of squamous metaplasia in the development of low grade squamous intraepithelial lesions in young women. Cancer. 1999;85(5):1139-44. 
51. Simm S, Doltoniak D. The cytologic progression from benign to malignant changes in a cervical erosion. Gynaecologia. 1966;162(1):48-56

52. [Epidemiologic factors in cervical cancer--investigation on 306 pairs of partners. Jiangxi Co-operative Group of Cervical Cancer]. Zhonghua Zhong Liu Za Zhi. 1986;8(6):444-6.

53. Zhang GN, Xu AQ. [Conditional logistic regression analysis and path analysis of risk factors of cervical cancer]. Zhonghua Liu Xing Bing Xue Za Zhi. 1990;11(4):212-6.

54. Juneja A, Murthy NS, Sharma S, Shukla DK, Roy M, Das DK. Selective cervical cytology screening: discriminant analysis approach. Neoplasma. 1993;40(6):401-4.

55. Murthy NS, Sehgal A, Satyanarayana L, et al. Risk factors related to biological behaviour of precancerous lesions of the uterine cervix. Br J Cancer. 1990;61(5):732-6.

56. Kanka J, Subrt I, Stolz J, Svoboda B. Die Bedeutung der Elektrodiathermokoagulation in der Prävention des Zervixkrebses. [The significance of electrodiathermocogulation in the prevention of cervix cancer]. Z Geburtshilfe Gynakol. 1968;169(3):289-96.

57. Bouda J, Dohnal V. [On the problem of cancer prophylaxis by electrocoagulation in cervical erosion and in the changing zone]. Geburtshilfe Frauenheilkd. 1965;25(12):1186-94.

58. Peyton FW, Peyton RR, Anderson VL, Pavnica P. The importance of cauterization to maintain a healthy cervix. Long-term study from a private gynecologic practice. Am J Obstet Gynecol. 1978;131(4):374-80.
59. Kauraniemi T, Räsänen-Virtanen U, Hakama M. Risk of cervical cancer among an electrocoagulated population. Am J Obstet Gynecol. 1978;131(5):533-8.

60. Vonka V, Kanka J, Jelínek J, et al. Prospective study on the relationship between cervical neoplasia and herpes simplex type-2 virus. I. Epidemiological characteristics. Int J Cancer. 1984;33(1):49-60.

61. De Punzio C, Fiore N, Vecoli LE, Pomponi P, Nuzzi FM, Teti G. Is electrodiathermy coagulation (EDC) of cervical ectropion effective in the prevention of cervical carcinoma? Eur J Gynaecol Oncol. 1984;5(2):131-4.

62. La Vecchia C, Franceschi S, Decarli A, Fasoli M, Gentile A, Gritti P. Electrocoagulation and the risk of cervical neoplasia. Obstet Gynecol. 1985;66(5):703-7.

63. Dalmaso ASW. Estruturaçăo e transformaçāo da prática médica: estudo de algumas características do modelo de trabalho na segunda metade do século XIX e início do século XX. [dissertation]. São Paulo: Faculdade de Medicina da Universidade de São Paulo; 1991.

64. Gonçalves RBM. Tecnologia e organizaçăo social das práticas de saúde: características tecnológicas do processo de trabalho na rede estadual de centros de saúde de São Paulo. São Paulo: Hucitec; 1994.

65. Schraiber LB. O médico e seu trabalho: limites da liberdade. São Paulo: Hucitec; 1993

66. Faúndes A, Telles E, Cristofoletti ML, Faúndes D, Castro S, Hardy $\mathrm{E}$. The risk of inadvertent intrauterine device insertion in women carriers of endocervical Chlamydia trachomatis. Contraception. 1998;58(2):105-9.
67. Codes JS, Cohen DA, Melo NA, et al. Detecçāo de doenças sexualmente transmissiveis em clínica de planejamento familiar da rede pública no Brasil. [STD screening in a public family planning clinic in Brazil]. Rev Bras Ginecol Obstet. 2002;24(2):101-6.

68. Ferraz do Lago R, Simōes JA, Bahamondes L, Camargo RP, Perrotti M, Monteiro I. Follow-up of users of intrauterine device with and without bacterial vaginosis and other cevicovaginal infections. Contraception. 2003;68(2):105-9.

Sources of funding: None

Conflict of interest: None

Date of first submission: April 9, 2007

Last received: March 7, 2008

Accepted: March 7, 2008

\section{AUTHOR INFORMATIDN}

Luís Carlos Machado Junior, MD, MSc. Gynecologist, Centro de Saúde Escola Samuel Barnsley Pessoa, Faculdade de Medicina da Universidade de São Paulo (FMUSP), São Paulo, Brazil.

Ana Silvia Whitaker Dalmaso, MD, PhD. Medical hygienist, Centro de Saúde Escola Samuel Barnsley Pessoa, Faculdade de Medicina da Universidade de São Paulo (FMUSP) São Paulo, Brazil.

Heráclito Barbosa de Carvalho, MD, PhD. Professor, Department of Preventive Medicine, Faculdade de Medicina da Universidade de São Paulo (FMUSP), São Paulo, Brazil.

Place where the paper was presented: Master's degree defense by Luis Carlos Machado Junior, Faculdade de Medicina da Universidade de São Paulo (FMUSP), May 18,2004

\section{Address for correspondence:}

Luís Carlos Machado Junior

Av. Dr. Vital Brasil, 1.490 - Butantã

São Paulo (SP) - Brasil - CEP 05503-000

Tel. (+55 11) 3726-8452 - Fax. (+55 11) 3726-2912

E-mail: csesbp@usp.br

Copyright $\odot$ 2008, Associação Paulista de Medicina

\section{Evidências de benefícios no tratamento de ectopia do colo do útero: revisão de literatura \\ CONTEXTO E OBJETIVO: A ectopia do colo do útero é hoje considerada um fenômeno fisiológico, mas parece ainda haver uma forte tendência no sentido da intervenção (tratamento). Este estudo se propõe a realizar} revisão da literatura buscando evidências de benefícios conseqüentes ao tratamento da ectopia.

MÉTODOS: Pesquisa nas bases Medical Literature Analysis and Retrieval Sysem Online (Medline), Excerpta Medica Database (Embase), Literatura Latino-Americane e do Caribe em Ciências da Saúde (Lilacs), Biblioteca Cochrane e seis livros especializados.

RESULTADOS: A revisão mostrou que: 1) existe provavelmente associação de ectopia com infecção cervical por Chlamydia trachomatis, pelo vírus HPV e maior risco de soroconversão para HIV; 2) existe provavelmente associação entre ectopia e neoplasia intra-epitelial cervical; 3) existe associação com mucorréia e nictúria; 4) não existem evidências sobre associação entre ectopia e câncer de colo do útero nem sobre proteção contra este câncer proporcionada pelo tratamento da ectopia.

CONCLUSÕES: 1) Não foram encontrados na literatura dados que justifiquem o tratamento rotineiro da ectopia; 2) O tratamento pode ser utilizado para tratar sintomas associados à ectopia, porém mais sintomas são atribuídos à ectopia do que se pôde confirmar em um estudo controlado; 3) Seriam necessários novos estudos para testar a hipótese de proteção contra o câncer de colo proporcionada pelo tratamento.

PALVRAS-CHAVE: Erosão cervical uterina. Cervicite uterina. Neoplasia intra-epitelial cervical. Doenças do colo do útero. Neoplasia do colo do útero. 